\title{
КООПЕРАТИВЫ КАК АЛЬТЕРНАТИВНАЯ «НЕФИНАНСОВАЯ» СИСТЕМА РЕСУРСООБЕСПЕЧЕНИЯ
}

\section{(c) 2020 Будович Юлия Ивановна}

доктор экономических наук, доцент, профессор Департамента экономической теории Финансовый университет при Правительстве Российской Федерации, Россия, Москва

E-mail: JBudovich@fa.ru

ORCID: https://orcid.org/0000-0001-8691-947X

В настоящей статье делается попытка раскрыть основные положения теории нефинансовой экономики применительно к кооперативам, выступающим с точки зрения данной теории альтернативным нефинансовым способом решения целого ряда проблем социально-экономического развития. На примере кооперативов показана альтернативность финансовых и нефинансовых систем ресурсообеспечения, вытеснение нефинансовыми системами финансовых альтернатив, непоследовательность государства в поддержке нефинансовых систем, их большая эффективность по сравнению с финансами, нелинейный характер развития нефинансовых систем обеспечения и противодействие их развитию со стороны финансовых альтернатив.

Ключевые слова: нефинансовая экономика, система ресурсообеспечения, кооператив, нефинансовая капитальная система.

Нефинансовая экономика (экономика без финансов) - направление экономико-теоретического исследования, рассматривающее социально-экономическое развитие через призму единства и борьбы финансовых и нефинансовых систем его обеспечения (финансов и нефинансов). Она исходит из того, что у всех финансовых (основанных на трансфертных сделках) систем обеспечения (налоговых, кредитных, страховых, капитальных, валютных и т.д.) имеются конкурирующие нефинансовые (основанные на товарообменных сделках) заменители, например у банковского потребительского кредита - «исламский» потребительский кредит (банк сам приобретает требуемую его клиенту вещь, а затем перепродает ее этому клиенту по более высокой цене с рассрочкой платежа), у кредита на покупку оборудования - лизинг (сдача в аренду) оборудования. При этом какая-то нефинансовая система обеспечения может выступать заменой одновременно нескольких разноотраслевых финансовых систем, например, возмездная трудовая деятельность выступает заменой и пособий по безработице, и пенсий по старости, и воровства денег, относящихся к таким отраслям ресурсообеспечения (имеющим «финансовые» названия), как субсидии, пенсии и кража соответственно [1, с. 25-26, 31, 149-160].

Нефинансовая экономика отмечает нали- чие в мире в последние десятилетия процесса вытеснения финансов нефинансами (идущего, зачастую, при активной, хотя и весьма непоследовательной, господдержке, например, в РФ задерживается разработка нормативно-правовой основы для развития исламского банкинга [18 c. 78]). Так, в последние десятилетия исламский кредит развивается быстрее традиционного банковского кредита, лизинг оборудования от банковских структур «теснит» традиционный кредит на приобретение оборудования [14, с. 50]. Этот процесс объясняется большей приемлемостью (большими экономичностью, доступностью и безопасностью) нефинансовых систем обеспечения по сравнению с финансовыми, как для клиентов, так и для самих ресурсодателей. Так, бартер - нефинансовая система ресурсообеспечения, замещающая кредит и банковскую платежную систему - все более популярен у малого и среднего бизнеса (МСБ). Он более: экономичен (не нужно платить проценты по кредитам, взятым для приобретения товаров), доступен (для закупки товаров нужны лишь собственные товары, тогда как для закупки товаров за деньги нужны кредиты, малодоступные для МСБ), безопасен (безналичные деньги, приготовленные для закупки товаров, могут быть заморожены в связи с проблемами в работе банка, списаны за долги, просто украдены со счета, а свои това- 
ры со своего же склада никуда не денутся) [1, с. 109-110].

Процесс развития нефинансовых систем обеспечения во всех отношениях носит весьма нелинейный характер, в частности доля нефинансовых систем в решении каких-то проблем может сокращаться, и даже возможно полное исчезновение каких-то систем на некоторое время. Торможение развития и исчезновение каких-то нефинансовых систем обеспечения, если оно не связано с заменой их более эффективными нефинансами, объясняется нефинансовой экономикой явным или неявным противодействием их развитию, оказываемым финансовыми альтернативами, прежде всего, посредством регулирующего нефинансовые системы законодательства, т.е. руками того же государства. Этим объясняется и непоследовательность государственной поддержки развития нефинансовых систем. «Недоработки» законодательства ликвидируют преимущества нефинансовых способов решения проблем, например, их относительную безопасность, в связи с чем доля финансов в решении этих проблем увеличивается. Зачастую, под видом защиты общества от «плохих» нефинансов, соответствующие нефинансовые системы законодательно запрещаются. Пример такой «расправы» финансов над нефинансами недавно взятый курс на отмену традиционного «нефинансового» долевого строительства, обосновываемый необходимостью решения проблемы «обманутых дольщиков». При новом порядке покупатели квартир в строящемся доме перечисляют деньги не на счет застройщика, а на «эскроу-счет» в банке, на котором они будут храниться до тех пор, пока застройщик не построит дом, и дольщики не оформят права собственности на квартиры. И застройщикам разрешается привлекать деньги на строительство только в банках [1, с. 22]. Превращение долевого строительства в финансовую систему обеспечения его деньгами означает удорожание стоимости жилья, прежде всего, за счет включения в его себестоимость банковских процентов. Эксперты еще при появлении соответствующей инициативы отмечали, что проблема обманутых дольщиков может быть решена в рамках традиционного долевого строительства путем усиления требований к застройщикам и страховщикам, что эта инициатива проводится не в интересах населения и бизнеса, а нацелена на жизнеобеспечение банков, прибыли которых сократились, их «озолочение» [11].

Цель настоящей статьи состоит в том, чтобы показать, что все сказанное выше о нефинансах в их отношении к финансам (альтернативность финансовых и нефинансовых систем обеспечения при решении проблем, одна нефинансовая альтернатива заменяет несколько разноотраслевых финансовых систем, идет в целом процесс вытеснения финансов нефинансами, непоследовательность господдержки последних, нелинейность процесса развития нефинансов, противодействие развитию нефинансов со стороны финансов) в полной мере относится и к кооперативам.

Кооператив - система коллективного хозяйствования, решающая нефинансовыми способами целый ряд проблем, прежде всего проблем его учредителей. В той мере, в какой государство содействует развитию кооперативов с соответствующими целями, данные проблемы посредством кооперативов решает и государство. Одной из проблем, решаемых посредством кооперативов, является недостаточное развитие отдельных видов деятельности. Она решается, в частности, посредством учреждения и расширения предприятий. Учреждение и, в значительной мере, расширение предприятий осуществляется посредством системы ресурсообеспечения «капитал», т.е. системы наделения предприятия собственными средствами (средствами его учредителей). В ней также есть финансовая и нефинансовая разновидности. Для финансовой характерно то, что в обмен на учредительские взносы (деньги, оборудование и т.д.) учредители получают в собственность свидетельства о взносе средств (акции и др.), или уставный (фиктивный) капитал, в то время как сами взносы становятся собственностью предприятия, а для нефинансовой - то, что в обмен на взносы учредители получают в собственность имущество предприятия, или физический (реальный) капитал. Капитальная система кооператива является нефинансовой - его пайщики становятся собственником именно имущества предприятия, которое принадлежит им на праве общей собственности. Таким образом, кооператив, в данном случае производственный, является нефинансовым способом решения проблемы недостаточного роста (развития) отдельных производств посредством учреждения новых предприятий или увеличения их собственных средств. 
Учредители производственного кооператива (ПК) решают посредством кооператива проблему трудоустройства (ПК предполагает личное трудовое участие учредителей в деятельности предприятия), закупочного - обеспечения своих хозяйств качественными и дешевыми продуктами, сбытового - сбыта своей продукции по достойным ценам, жилищно-накопительного (ЖНК) - отсутствия денег для приобретения жилья, жилищно-строительного кооператива (ЖСК) - высокой стоимости жилья или его отсутствия. Данные проблемы решаются посредством кооперативов также на основе сделок купли-продажи товаров, в связи с чем и в этих случаях кооперативы выступают нефинансовыми способами их решения. Так, проблема трудоустройства решается путем обмена учредительского взноса на долю в имуществе кооператива (поскольку только наличие средств производства в собственности у какого-то лица гарантированно обеспечивает его работой), проблема обеспечения качественными и дешевыми продуктами - путем покупки таких продуктов, проблема сбыта продукции по достойным ценам - путем продажи продукции по таким ценам, проблема отсутствия денег для оплаты жилья - путем покупки жилья, в том числе, за счет средств, полученных ЖНК от продажи долей в своем имуществе новым пайщикам, проблема высокой цены на жилье и его отсутствия - путем получения в обмен на паевой взнос доли в имуществе ЖСК и последующего получения в собственность от ЖСК жилья в обмен на эту долю.

Кооператив является альтернативным нефинансовым способом решения проблем, т.е. те же проблемы решаются и финансовыми способами. Проблема недостаточного развития сельского хозяйства, решавшаяся путем первоочередного развития колхозов, выступавших сельскохозяйственными производственными кооперативами (СПК), после смерти И. В. Сталина в 1953 г. вплоть до начала 1980-х гг. решалась путем первоочередного развития совхозов - государственных предприятий, имущество которых находилось в собственности (хозяйственном ведении) самих предприятий, т.е. предприятий, имевших финансовую капитальную систему. Если в 1953 г. в 4,9 тыс. совхозах работало 1,8 млн. чел. [19, с. 128, 135], то в 1980 г. уже в 21,1 тыс. совхозах трудилось 11,6 млн. чел. [20, с. 277, 286], т.е. число совхозов выросло в 4,3 раза $(21,1 / 4,9)$, а среднегодовая численность их работников - в 6,4 раза
$(11,6 / 1,8)$. Колхозная форма хозяйствования, в свою очередь, относительно и абсолютно сокращалась, в том числе за счет реорганизации колхозов в совхозы (в 1957-1964 гг. 20254 колхоза были преобразованы в 4880 совхоза [4]). Если в 1953 г. в 93,3 тыс. колхозов было 19,7 млн. колхозных дворов [19, с. 128, 135] (число колхозников несколько больше числа дворов), то в 1980 г. уже в 25,9 тыс. колхозах трудились 13,3 млн. колхозников [20, с. 277, 286], т.е. число колхозов уменьшилось в 3,6 раза $(93,3 / 25,9)$, а среднегодовая численность колхозников сократилась как минимум в 1,5 раза $(19,7 / 13,3)$. Пример альтернативности ПК и финансовых (по характеру капитальной системы ресурсообеспечения) форм хозяйствования из жизни современной России перерегистрация в акционерные общества и общества с ограниченной ответственностью СПК, доля которых в численности сельскохозяйственных предприятий упала с 50,4\% в 2003 г. до 22,2\% в 2015 г. (в них осталось 18\% сельхозугодий и 750 тыс. занятых) [17, с. 107].

Трудоустройство посредством учреждения ПК является альтернативой такому финансовому способу решения проблемы поиска работы, как бесплатные услуги по трудоустройству, оказываемые безработным государственной службой занятости, такому финансовому способу поддержки безработных, как пособия по безработице. Обеспечение хозяйства качественными и дешевыми продуктами посредством снабженческого кооператива - бюджетным субсидиям производителям соответствующих продуктов. Сбыт продукции по достойным ценам посредством сбытового кооператива - бюджетным субсидиям, получаемым учредителями сбытового кооператива. Решение проблемы недостатка денег для покупки жилья путем вступления в ЖНК - ипотеке (см. ниже). Решение проблемы дороговизны жилья посредством ЖСК - финансовому долевому строительству (см. выше). Решение проблемы отсутствия жилья посредством ЖСК - бесплатному предоставлению жилья государством определенным категориям граждан. Именно на замену последнего в современной России пришли ЖСК, создаваемые по № 161-Ф3 «О содействии жилищному строительству». Как отметила председатель Комитета Государственной Думы по жилищной политике и ЖКХ Г. Хованская, бюджетники и многодетные семьи, перед которыми у государства есть обязательства по улучшению жилищных условий, с помощью 
«социальных» ЖСК (стоимость приобретаемого через них жилья может оказаться до 50\% ниже рыночной - за счет бесплатного получения от государства земли, отсутствия девелоперских затрат и самостоятельного контроля членов ЖСК за расходами на проектные работы) могут на более мягких условиях, чем рынок или ипотека, решить проблему жилья, не стоя в очереди за ним 25 лет [36].

Кооператив выступает альтернативой финансовым системам, относящимся к нескольким отраслям финансов. Так, в перечисленных выше случаях кооператив выступает конкурентом: 1) финансовой разновидности капитала (при развитии крупного сельскохозяйственного производства на основе СПК), 2) натуральных и денежных субсидий (при решении проблем трудоустройства, обеспечения дешевыми и качественными товарами, сбыта товаров по достойным ценам, отсутствия жилья), 3) кредита (при решении проблем недостатка денег для покупки жилья и высоких цен на жилье).

В последние десятилетия кооперативы вытесняют альтернативные финансовые способы решения проблем. Исходя из того, что кооперативы выступают альтернативой, главным образом, финансовым способам решения различных проблем, подтверждением этого тезиса может быть опережающий рост кооперированного населения Земли по сравнению с населением Земли в целом. Если в начале века в мире кооперативы объединяли 800 млн. чел. [35, с. 12], то, по данным Worldwatch Institute (2012), в 96 странах насчитывался 1 млрд. членов кооперативов [16], т.е. кооперированное население Земли увеличилось за соответствующий период на $25 \%$ ((1000-800)/800*100). В 2000 г. население Земли составляло 6,089 млрд. чел., а в 2012 г. оно достигло 7,057 млрд. [9], т.е. увеличилось только на $16 \%((7,057-6,089) / 6,089 * 100)$. Да и, по мнению некоторых экспертов, в современной истории нет социально-экономической организации, сравнимой по темпу распространения с кооперативом. В связи с этим мировая экономика даже стала трактоваться как трехсекторная, состоящая из частного, кооперативного и государственного секторов [29].

«Кооперативные» способы решения проблем, разумеется, при прочих равных условиях, являются более эффективными (более дешевыми, доступными и безопасными), чем финансовые способы их решения.
Так, проблема коллективизации сельского хозяйства, т.е. перехода от мелкого (на основе единоличных хозяйств) к крупному сельскохозяйственному производству, решенная в 1937 г., когда в колхозы было объединено 93\% крестьянских хозяйств [7], решалась советским государством именно кооперативным способом. Он был значительно более дешевым, чем коллективизация на базе совхозов, так как для последней потребовался бы выкуп у крестьян прав пользования землей и производственного имущества сельскохозяйственного назначения (скота, мельниц, инвентаря и т.д.) с последующей их передачей совхозам. Колхозный путь коллективизации такого выкупа не требовал, так как объединяемое имущество оставалось в собственности крестьян (переходя в их общую собственность). Колхозы были более доступны советскому государству, чем совхозы, в том смысле, что убедить крестьянина вступить в колхоз было значительно проще, чем убедить его отказаться от собственного хозяйства, т.е. от статуса руководителя и владельца собственного предприятия, а также от связанного с этим положением дохода, в том числе прибыли предприятия, даже за деньги, особенно в условиях НЭПа, и пойти работать на государственное сельскохозяйственное предприятие в качестве «бесправного» наемного работника за одну зарплату. Конечно же, у советского государства была возможность заполучить в собственность производственное имущество крестьян путем его конфискации, обеспечив тем самым бесплатность и доступность соответствующей трансакции, но этим оно безмерно увеличило бы ее токсичность (опасность), в связи с чем этот способ решения проблемы всерьез не рассматривался. Такая экспроприация вызвала бы крестьянское восстание в стране. Накануне сплошной (массовой) коллективизации, проходившей в 1929-1937 гг., а именно в 1928 г., в стране, по данным советских источников, к крестьянам-единоличникам, причем даже без кулаков, и некооперированным кустарям относилось $74,9 \%$ населения, в том числе к последним $-1,2 \%$ населения [6, с. 20], из чего следует, что крестьяне-единоличники составляли $73,7 \%$ населения страны $(74,9-1,2)$, т.е. основную его массу. Это значит, что подавить такое восстание советскому государству было бы очень сложно. При этом восстание крестьян вызвало бы восстание рабочих - по причине недостатка продовольствия в городах из-за неизбежного падения 
в результате борьбы с крестьянами сельхозпроизводства и нарушения продуктообмена между городом и деревней, в связи с чем советская власть, скорее всего, была бы сметена. О крайней токсичности принудительных трансакций с крестьянской собственностью предупреждали всего лишь «перегибы» в массовой коллективизации, имевшие место в 1929-1932 гг., т.е. действия, не связанные с отъемом собственности, вызвавшие в 1929 г. (массовая коллективизация началась в декабре) 86 массовых выступления крестьян, а в 1930 г.- 7382 таких выступления! Крайней токсичностью характеризовались любые антикрестьянские действия, например, в 1930 г. ущемление церковнослужителей и кулаков вызвало 2339 волнений, закрытие церквей и снятие колоколов - 1487, и т.д., а общее количество массовых выступлений крестьян в 1930 г. составило 13754 [15]. Токсичность совхозной коллективизации также состоит в нанесении совхозами убытков государственной казне в связи с необходимостью их более значительной поддержки в случае затруднений, как менее эффективной формы хозяйствования, чем колхозы (см. ниже).

Кстати, и решение проблемы низких темпов роста уже крупного производства на селе, возникшей после Второй мировой войны, посредством поддержки колхозов было более приемлемым для нашей страны, чем ее решение посредством развития совхозного строя, которое реализовывалось в 1953-1980 гг. (см. выше). Прежде всего, «колхозное» решение данной проблемы было более дешевым (экономичным) с точки зрения вложений средств на единицу выпуска. Постоянно действовавшим фактором более рентабельной работы колхозов по сравнению с совхозами было то, что колхозники являлись реальными собственниками имущества колхозов, т.е. лицами, заплатившими за него реальные средства, в то время, как работники совхозов не были собственниками имущества совхозов (при централизованной системе управления госпредприятиями) либо числились таковыми лишь формально (при предоставлении госпредприятиям хозяйственной самостоятельности). Наличие же у работников предприятия реальной собственности на его имущество (на средства производства и продукты труда) сообщает им дополнительный стимул к труду и бережливому отношению к имуществу предприятия. «Совхозное» решение проблемы объяснялось, естественно, более высокой эффективностью (прежде всего, экономичностью) совхоза по сравнению с колхозом, выступающей неизбежным следствием общественной (всего народа), а не общей (работников предприятия) собственности на имущество совхоза. Однако расчеты, основанные на официальных статистических данных, говорят об ином.

В 1970 г. среднегодовая численность колхозников составляла 16,7 млн. чел., валовая продукция сельского хозяйства колхозов - 42,3 млрд. руб., их производственные основные фонды сельскохозяйственного назначения $-42,6$ млрд. руб. В том же году среднегодовая численность работников совхозов была равна 8,9 млн. чел., валовая продукция сельского хозяйства колхозов 29,5 млрд. руб., их производственные основные фонды сельскохозяйственного назначения 36,9 млрд. руб. [20, с. 277, 286]. По этим данным можно установить, что в 1970 г. годовая производительность труда колхозника составила 2,53 млн. руб. (42,3/16,7), а работника совхоза $-3,31$ млн. руб. (29,5/8,9), фондовооруженность труда колхозника была 2,55 млн. руб. (42,6/16,7), а работника совхоза $-4,15$ млн. руб. $(36,9 / 8,9)$. Но при этом производительность труда в совхозах была на $31 \%$ (3,31/2,53-1) больше, чем в колхозах, тогда как его фондовооруженность - на 63\% (4,15/2,55-1) больше, т.е. большая производительность труда в совхозах достигалась за счет непропорционально более высокой его фондовооруженности. Однако эти данные лишь косвенно говорят о большей эффективности колхозов, так как рост фондовооруженности труда в колхозах на 63\% может быть связан с меньшим, чем на $31 \%$, ростом производительности труда, что покажет меньшую эффективность колхозов по сравнению с совхозами.

При этом в последующие годы вплоть до крушения СССР наблюдается картина выравнивания фондовооруженности труда в колхозах и совхозах при более быстром росте производительности труда в колхозах, почти догнавшей данный показатель совхозов. В 1990 г. среднегодовая численность колхозников была 11,8 млн. чел., валовая продукция сельского хозяйства колхозов - 78,2 млрд. руб., фондоотдача (отношение предыдущего показателя к производственным основным фондам сельскохозяйственного назначения) -486 руб. В том же году среднегодовая численность работников совхозов составила 11,0 млн. чел, валовая про- 
дукция сельского хозяйства колхозов - 77,5 млрд. руб., фондоотдача - 417 руб. [21]. Отсюда, в 1990 г. годовая производительность труда колхозника составила 6,63 млн. руб. $(78,2 / 11,8)$, а работника совхоза - 7,05 млн. руб. $(77,5 / 11,0)$, фондовооруженность труда колхозника - 13,6 млн. руб. (78,2/0,486/11,8), а работника совхоза - 16,9 млн. руб. (77,5/0,417/11,0). При этом производительность труда работника совхоза в 1990 г. была больше на 6\% (7,05/6,63-1), чем колхозника, а фондовооруженность его труда - на $24 \%$ (16,9/13,6-1) больше. Как и раньше, более высокая производительность труда в совхозах достигается за счет непропорционально более высокой его фондовооруженности. При этом видно, что за 20 лет (1990-1970) процент сокращения разницы в фондовооруженности давал 0,64\% ((31-6)/(63-24)*100) сокращения разницы в производительности труда. Это говорит о том, что полное выравнивание фондовооруженности труда в колхозах и совхозах могло бы привести (если бы не ликвидация колхозно-совхозного строя на селе в новой России) к такому росту производительности труда в колхозах, в результате которого она превысит производительность труда в совхозах на $9 \%(24 * 0,64-6)$.

Решение проблемы поиска работы посредством учреждения ПК является более дешевым, доступным и безопасным, чем с помощью государственной службы занятости. Более дешевым - даже несмотря на то, что учреждение кооператива связано с осуществлением паевых взносов, а получение работы из рук службы занятости формально является бесплатным. Прежде всего, полезности, получаемые при первом и втором способах решения проблемы несопоставимы. Если ПК позволяет «заняться любимым делом в компании увлеченных единомышленников» [10], то лицо, получающее работу через службу занятости, может о такой работе только мечтать. Если доходы кооператоров ограничены только маржой, налогами и нормой накопления, то пользователям услуг службы занятости будет предложена самая мизерная зарплата при самых худших условиях труда, так как предприятия, предлагающие вакансии через службу занятости, стремятся по максимуму воспользоваться затруднительным положением безработных. Как показал эксперимент по поиску работы через органы службы занятости, проведенный еще в 2015 г. Аи Ф.ru, с их помощью найти работу, соответствующую требованиям соискателя и его квалификации, крайне проблематично (это «большой вопрос»), и этого не гарантирует долгое ожидание хорошей вакансии. Что касается зарплаты и режима труда, то претендентке, средняя зарплата которой до увольнения с прежнего места работы в типографии по специальности «филолог» составляла 55 тыс. руб., была предложена работа помощника руководителя негосударственного вуза по 6 дней в неделю с 8 до 18 часов с зарплатой 12 тыс. руб., причем оклад составлял всего 5 тыс. руб., а остальное - премия, которую «еще надо заработать» [37]. По данным обследования населения по проблемам занятости, проведенного в 2018 г. в Приморском крае, средняя продолжительность поиска работы зарегистрированными безработными на конец 2018 г. составила 4,6 мес., и больше года поиском работы занимались 8\% безработных [33]. С помощью же юридических фирм зарегистрировать ПК можно за 3 недели - 1 месяц [30]. Эти данные, говорящие о большей доступности кооперативного способа решения проблемы поиска работы, также говорят о том, что «бесплатные» услуги государства по поиску работы в действительности имеют стоимость, которая равна величине дохода от участия в кооперативе, недополученного безработным в течение срока, равного разнице между временем, затрачиваемым на получение работы через биржу труда и необходимым для регистрации кооператива. Так что дешевизна единицы полезности работы, предоставляемой кооперативом, по сравнению с ее стоимостью, получаемой через службу занятости, может быть реально измерена. Большая доступность кооперативного способа также состоит в том, что учредителю ПК для трудового участия в его деятельности, в отличие от наемного работника, не требуется оформление трудового договора [27]. Его большая безопасность состоит в том, что член кооператива может лишиться работы со значительно более низкой вероятностью, чем получивший работу через службу занятости, т.е. наемный работник, потому, что решение о том, работать или не работать на предприятии, в значительно большей степени зависит от члена кооператива, чем аналогичное решение - от наемного работника.

Решение проблемы недостатка денежных средств для приобретения жилья посредством членства в ЖНК, при прочих равных условиях, является более дешевым, доступным и безопасным способом ее решения, нежели чем по- 
средством ипотеки. Лица, прибегшие к покупке жилья через ЖНК, объясняют свой выбор в пользу «некредита» как раз рассмотренными выше относительными дешевизной, доступностью и безопасностью кооператива по сравнению с финансами. Так, Т.Смирнова, подробно изложившая свой опыт покупки жилья путем вступления в ЖНК, отметила, что в ЖНК вступают люди, не желающие переплачивать банкам по ипотеке (сама она сэкономила 130 тыс. руб. на покупке однокомнатной квартиры стоимостью 2,3-2,4 млн. руб.), и те, кому в ипотечном кредите банки отказали [31], т.е. указала на относительную дешевизну и доступность соответствующего способа решения проблемы недостатка денег для покупки жилья.

Развитие кооперативов происходит зачастую при активной поддержке государства, но она является непоследовательной. Безусловно, само решение о введении ЖСК с господдержкой (социальных ЖСК) можно считать мерой активной поддержки государством соответствующей нефинансовой системы обеспечения - системы ЖСК. Однако Правительство РФ утвердило в соответствии с законом № 161-Ф3 «О содействии развитию жилищного строительства», принятом еще в 2008 г., Типовой устав ЖСК с господдержкой только в 2012 г. [13]. И дальнейшие шаги государства в отношении ЖСК с господдержкой можно охарактеризовать как непоследовательность в развитии этой нефинансовой системы обеспечения. С 2012 г. стало осуществляться предоставление земель в безвозмездное пользование социальных ЖСК [28], однако положения закона № 161-Ф3, регулировавшие их деятельность, были таковы (например, условие о передаче земельных участков после внесения 20\% паевых взносов, требование соответствия жилья экономическому классу), что эти ЖСК практически не развивались - в 2016 г. в них было зарегистрировано только 10 тыс. чел. [12]. О мизерности участия социальных ЖСК в решении жилищной проблемы в России говорят целевые ориентиры по ее решению, прозвучавшие в президентском послании В.В.Путина Федеральному Собранию от 1 марта 2018 г.: увеличение числа семей, улучшивших жилищные условия, с 3 до 5 млн. в год или увеличение объема жилищного строительства с 80 до 120 млн. кв. м в год [24]. Ряд положений этого закона, сдерживавших развитие социальных ЖСК, был отменен только с 1 сентября 1916 г. [12]. И после этого, очевидно, механизм социальных ЖСК нормально не заработал, так как еще в начале 2019 г. на встрече с В.В.Путиным в Казани один из ее участников отметил, что после попытки реанимировать программу организации ЖСК некоторое время назад, закончившейся созданием 15-20 кооперативов, дело заглохло [28]. Но, наверное, дело с места все же тронулось, так как, если в 2018 г. социальными ЖСК было построено 35,6 тыс. кв. м жилья, то в 2019-110 тыс., т.е. в 3 раза больше $(110 / 35,6)$ [2]. Тем не менее, участие социальных ЖСК в решении жилищной проблемы продолжает оставаться ничтожно малым - 110 тыс. от 80 млн. составляет всего чуть более $0,1 \%(110 / 80000 * 100)$.

Процесс развития кооперативов во всех отношениях носит весьма нелинейный характер. Эта нелинейность наблюдается, прежде всего, в масштабах всего мирового кооперативного движения. В его развитии можно выделить два периода бурного роста (с середины XIX в., когда произошло становление кооперативов, до начала Первой мировой войны и с начала 1990-х гг. по настоящее время (см. выше)), разделенных периодом кризиса. При этом в развитии кризиса кооперативного движения приняли активное участие государства. Кризис объясняется, в частности, политикой ликвидации кооперативов, которую проводили в 1920-1930-е гг. фашистские режимы в Германии, Италии, Австрии, Венгрии и др., политикой банкротства и реорганизации кооперативов, проводившейся после Второй мировой войны в ФРГ, Голландии, Австрии и др., антикооперативной политикой, проводившейся в СССР (часть руководства Центросоюза СССР с конца 1935 г. была репрессирована и пр.) до Второй мировой войны и в странах социализма после нее (ликвидация национальных кооперативных центров и передел их имущества и пр.) [29]. За соответствующей государственной политикой, как и в общем случае борьбы с нефинансами, так или иначе просматривается направляющая рука финансов. Согласно работе (Сорокина, Зарубина, 2011), в XX в. ослабить кооперативное движение или уничтожить кооперативы пытались монополии, что особенно ухудшило ситуацию в кооперативном движении в 1960-е гг. [32], а монополии представляли собой акционерные общества, относящиеся к финансовой форме хозяйствования.

Примеры нелинейности развития отдельных видов кооперативов в изобилии представлены в хозяйственной истории нашей страны после 
Октябрьской революции 1917 г. Так, вначале жилищные кооперативы в советской стране были запрещены. После разрешения жилищных кооперативов в связи с переходом к НЭПу в 19211937 гг. произошло их бурное развитие. Именно посредством ЖСК был возведен знаменитый поселок «Сокол» рядом с одноименной станцией метро в Москве [3]. Развитие ЖСК тогда стало реакцией на жизнь в национализированной в 1917 г. городской недвижимости. Последствиями национализации стали: резкое ухудшение качества жилья (парадные входы заколочены, зеркала разбиты и т.д.), перенаселение («уплотнение») в результате превращения богатых квартир в коммуналки, куда переселяли бедноту из ночлежек и рабочих с окраин, неэффективное управление домами домовыми комитетами, жилищное социальное смешение, когда вместе жили люди разного социального, финансового и культурного уровня [23]. В терминах нефинансовой экономики развитие ЖСК было реакций на чрезвычайную дороговизну получения качественного и безопасного жилья соответствующим финансовым (бесплатно от государства) способом (т.е. на невозможность его получения) и на токсичность этого способа, проявлениями которой и были приведенные выше последствия национализации городского жилья. Жилищные кооперативы исчезли в 1937 г., но не из-за их неэффективности, а по причине их запрета как проявлений частной собственности [5].

После разрешения постановлением Совета Министров СССР жилищных кооперативов в 1958 г. ЖСК вновь претерпели бурное развитие. Доля ЖСК в объеме возводимого в СССР жилья достигала $10 \%$, причем на вступление в кооперативы существовала очередь [3]. По данным, приведенным первым заместителем председателя Комитета Совета Федерации по федеральному устройству, региональной политике и местному самоуправлению А.Шевченко, в РСФСР в 1970-1980-е гг. через ЖСК возводилось 8\% жилья [36]. Развитие ЖСК здесь было реакцией, главным образом, на недоступность жилья, бесплатно получаемого от государства. Печальная судьба ЖСК в современной России - их доля в возводимом жилье постепенно снижалась и составила в 2015 г. 0,7\% [5] - объясняется тем, что законодательство поставило ЖСК в условия, не выгодные по сравнению с другой нефинансовой системой обеспечения строительства, которой выступило возникшее при переходе к рынку до- левое строительство. Законодательные препоны продолжают сдерживать развитие ЖСК, несмотря на многое, сделанное в последние годы для их устранения. В целом доработка законодательства здесь идет в русле распространения на ЖСК требований к застройщикам, занимающимся долевым строительством. Значительный эффект ожидается от разрешения передачи пая в залог и оформления ипотеки. Но, по мнению экспертов, даже при этих изменениях кооператив безнадежно проигрывает. В 2017 г. в РФ было организовано всего 30 ЖСК, причем большинство - по № 161-ФЗ. Эксперты полагают, что возродить интерес к обычным ЖСК позволит снятие с них ограничений по этажности, из-за которых их подряды невыгодны для крупных и устойчивых девелоперов, введение отчислений ЖСК в компенсационный фонд, что может привлечь пайщиков, считают, что в противном случае останутся только ЖСК бывших дольщиков и социальные ЖСК [34], т.е. обычные ЖСК будут обречены на вымирание. Более того, обычные ЖСК в настоящее время вообще находятся под угрозой запрета, о чем говорит предложенная поправка к № 161-Ф3, позволяющая создавать ЖСК лишь: 1) при банкротстве застройщика, когда ЖСК нанимает подрядную организацию и достраивает объект, и 2) в случае социальных ЖСК [5].

Еще одним ярким примером нелинейности является развитие в нашей стране СПК (во времена СССР - колхозов). Выше уже получил освещение упадок колхозной формы хозяйствования в 1954-1980 гг. При этом 1929-1937 гг. были периодом, наоборот, бурного роста колхозов. Если в 1928 г. колхозное крестьянство и кооперированные кустари составляли 2,9\% населения, то в 1937 г. $-57,9$ [19, с. 19]. При этом в 1937 г. колхозное крестьянство составило $44,9 \%$ населения страны [22], и даже если исходить из того, что в 1928 г. всю данную группу населения представляло колхозное крестьянство, его доля в населении страны за 9 лет (1937-1928) выросла более чем в 15 раз $(44,9 / 2,9)$. Если в 1928 г. было 33,3 тыс. колхозов [7], то уже в 1932 г. - 211,7 тыс. [19, с. 128]. Число же совхозов в этом периоде «топталось на месте». Если в 1927 г. было около 5 тыс. совхозов [8], то в 1940 г. их число составило 4,2 тыс. [19, с. 135]. Резкие колебания числа СПК имели место и в современной России. Выше были приведены данные о более чем 3-кратном падении числа СПК $(14,4 / 4,5=3,2)$ в $2003-2015$ гг., т.е. 
за 12 лет (2015-2003). Однако в 1996 г. их было только 2,4 тыс. [17, с. 107], т.е. число СПК выросло в 1996-2003 гг., т.е. за 7 лет (2003-1996) в 6 раз $(14,4 / 2,4)$ !

Нефинансовая экономика учит искать за падениями нефинансовых систем обеспечения, прежде всего, интерес конкурирующих финансов. О том, что финансы имеют непосредственное отношение к борьбе с колхозным строем в нашей стране во времена СССР, лучше всего говорят программы Коммунистической партии СССР. Еще в Программе РСДРП, принятой в 1903 г., содержалось требование замены частной собственности на средства производства и обращения общественной [26], т.е. государственной, а в принятой XXII съездом КПСС в 1961 г. новой (третьей) Программе КПСС был уста- новлен четкий срок для завершения перехода к единой общенародной форме собственности (т.е. к государственному предприятию) в связи с созданием материально-технической базы коммунизма, построением в СССР в основном коммунистического общества - в 1980 г. [25]. С 1954 г. государственным предприятиям, в том числе совхозам, предоставляется хозяйственная самостоятельность, т.е. они фактически становятся собственниками государственного имущества, в связи с чем совхоз превращается в финансовую форму хозяйствования. Соответствующая финансовая капитальная система должна была поглотить нефинансовую колхозную, управляя соответствующим процессом на селе через Программу КПСС.

\section{Библиографический список}

1. Будович Ю.И., Лебедев К. Н. Место финансов в современной экономике (Экономика без финансов).- Краснодар: НИИ экономики ЮФО, 2020. 187 с.

2. Ввод ЖСК с господдержкой за год вырос втрое / ЦИАН. 03.02.2020. URL: https://beta10.cian.ru/novosti-vvodzhsk-s-gospodderzhkoj-za-god-vyros-vtroe-302481/ (дата обращения: 08.09.2020).

3. Велесевич С. Кооперативы по-новому: что такое ЖСК с господдержкой / NERS.ru. 15.12.2016. URL: https:// news.ners.ru/kooperativy-po-novomu-chto-takoe-zhsk-s-gospodderzhkoj.html (дата обращения: 08.09.2020).

4. Верхогляд Д. А. Преобразование колхозов в совхозы в 1960-1970-х гг.: причины и влияние изменения статуса хозяйствующего субъекта на реализацию права землепользования // Юристъ-Правовед. 2013. № 6 (61). С. $116-119$.

5. Волохина С. Для ЖСК придумали рамки // ИЗВЕСТИЯ. 20.06.2018. URL: https://iz.ru/756886/svetlanavolokhina/dlia-zhsk-pridumali-ramki (дата обращения: 08.09.2020).

6. Восленский M. Номенклатура. Господствующий класс Советского союза.-М.: Советская Россия совм. с МП Октябрь, 1991. 624 с. С. 20.

7. Данилов В.П. Коллективизация сельского хозяйства СССР. Советская историческая энциклопедия / Наука. Искусство. Величие. URL: http://history.niv.ru/doc/encyclopedia/soviet-historical/articles/1794/kollektivizaciyaselskogo-hozyajstva.htm (дата обращения: 01.10.2020).

8. Зеленин И.Е. Совхозы в первое десятилетие советской власти / Киев: Библиотека Украины. URL: https:// elibrary.com.ua/m/articles/view/СОВХОЗЫ-В-ПЕРВОЕ-ДЕСЯТИЛЕТИЕ-СОВЕТСКОЙ-ВЛАСТИ (дата обращения: 18.09.2020).

9. История населения земли / Население земли. URL: https://countrymeters.info/ru/World\#historical_population (дата обращения: 05.10.2020).

10. Как открыть кооператив и почему этого не стоит делать/INC.01.12.2016. URL: https://incrussia.ru/instruction/ instruktsiya_kak-otkryt-kooperativ-i-pochemu-etogo-ne-stoit-delat/ (дата обращения: 08.08.2020).

11. Кому выгоден запрет на покупку жилья по ДДУ / Саморегулирование. Публикации. 31.07.2015. URL: http:// sroportal.ru/publications/komu-vygoden-zapret-na-pokupku-zhilya-po-ddu/ (дата обращения: 08.09.2020).

12. Кооперативы по-новому: что такое ЖСК с господдержкой / ДОМ.РФ. 13.12.2016. URL: https://xn - d1aqf. xn-1ai/media/news/kooperativy_po_novomu_chto_takoe_zhsk_s_gospodderzhkoy/ (дата обращения: 05.10.2020).

13. Куцина С. ЖСК с государственной поддержкой // Экономика и жизнь. 26.01.2017. URL: https://www.eg-online. ru/article/335319/ (дата обращения: 05.10.2020).

14. Лебедев К. Н. Экономика без финансов // Вопросы экономики и права. 2018. № 6 (120). С. 45-53.

15. Массовые бунты и восстания крестьян в 1930 против коллективизации - 7382 выступления / Livejournal. 02.12.2008. URL: https://man-with-dogs.livejournal.com/495966.html (дата обращения: 30.09.2020).

16. Membership in Co-operative Businesses Reaches 1 Billion / Common Dreams. URL: https://www.commondreams. org/newswire/2012/02/22/membership-co-operative-businesses-reaches-1-billion (дата обращения: 16.09.2020). 
17. Минаков И. А. Сельскохозяйственные производственные кооперативы и перспективы их развития в России // Технологии пищевой и перерабатывающей промышленности АПК-продукты здорового питания. 2017. т. 3. С. $105-113$.

18. Мокина Л. С. Исламское финансирование в России и в мире: проблемы и перспективы // Вестник Прикамского социального института. 2017. № 3 (78). С. 74-80.

19. Народное хозяйство СССР: статистический сборник.- М.: Государственное статистическое издательство, 1956. 263 c.

20. Народное хозяйство СССР в 1985 г.: статистический ежегодник.- М.: Финансы и статистика / ЦСУ СССР, 1986. 655 c.

21. Народное хозяйство СССР в 1990 г.- М.: Финансы и статистика, 1991. 750 с. С. 427-544.

22. Народное хозяйство СССР в 1960 году. Статистический ежегодник.- М.: Госстатиздат ЦСУ СССР, 1961.943 с.

23. Национализация жилищного фонда в 1917 г. и первые шаги новой власти в жилищной сфере / TEXTARCHIVE. RU. URL: https://textarchive.ru/c-1702646-p3.html (дата обращения: 11.09.2020).

24. Послание Президента Российской Федерации от 01.03.2018 г. б/н / Президент России. URL: http://www. kremlin.ru/acts/bank/42902/page/2 (дата обращения: 02.09.2020).

25. Программа Коммунистической партии Советского Союза. Принята XXII съездом КПСС в 1961 году (третья в истории Партии). URL: http://aleksandr-kommari.narod.ru/kpss_programma_1961.htm (дата обращения: 12.10.2020).

26. Программа Российской социал-демократической рабочей партии. 1903 г. / Музей истории российских реформ имени П.А.Столыпина. URL: http://xn - e1aaejmenocxq.xn - p1ai/node/13690 (дата обращения: 23.09.2020).

27. Производственный кооператив: без иллюзий // Audit-it.ru. 06.11.2014. URL: https://www.audit-it.ru/articles/ account/court/a55/788277.html (дата обращения: 17.08.2020).

28. Путин поддержал идею расширения механизма жилищно-строительных кооперативов / ТАСС. 12.02.2019. URL: https://tass.ru/nedvizhimost/6106851 (дата обращения: 05.10.2020).

29. Развитие кооперации в различных странах / Библиотека онлайн. URL: https:/sinref.ru/000_ uchebniki/00800economica/001_lekcii_economica_08_raznoe_/327.htm (дата обращения: 31.07.2020).

30. Регистрация производственного кооператива / mcob. URL:/https://mcob.ru/services/registraciya-kooperativa/ (дата обращения: 29.09.2020).

31. Смирнова Т. Как я купила квартиру через жилищный кооператив. Альтернатива для тех, кто не хочет брать ипотеку / Т - Ж. 04.03.2019. URL: https://journal.tinkoff.ru/installment-sale/ (дата обращения: 27.08.2020).

32. Сорокина И.Э., Зарубина А. И. Роль кооперативов в глобальной экономике // Проблемы современной экономики. 2011. № 3 (39). С. 64-67.

33. Средняя продолжительность поиска работы зарегистрированными безработными составила 4,6 месяца / Рамблер новости. 24.01.2019. URL: https://news.rambler.ru/sociology/41615261-srednyaya-prodolzhitelnostpoiska-raboty-zaregistrirovannymi-bezrabotnymi-sostavila-4-6-mesyatsa/ (дата обращения: 29.09.2020).

34. Сухов О. Проблемы и риски кооперативного жилищного строительства в России / Индикаторы рынка недвижимости. 18.10.2019. URL: https:/www.irn.ru/articles/40805.html (дата обращения: 08.09.2020).

35. Теплова Л. Е. Основы потребительской кооперации:Учеб. пособие.-М.: Вита-Пресс, 2005.160 c. URL: https:// www.studmed.ru/teplova-le-osnovy-potrebitelskoy-kooperacii_16696e9.html (дата обращения: 05.10.2020).

36. Турцева Д. «Надо создать нормальные ЖСК, а не мошеннические, связанные с долевым строительством» / Реальное время. 30.10.2018. URL: https://realnoevremya.ru/articles/118549-v-rossii-budut-vozrozhdatzhilischno-stroitelnye-kooperativy (дата обращения: 02.09.2020).

37. Уварова Н. Эксперимент АиФ.ru: помогает ли служба занятности найти работу? // Аргументы и факты. 25.10.2015. URL: https://aif.ru/money/business/eksperiment_aif_ru_pomogaet_li_sluzhba_zanyatnosti_nayti_ rabotu (дата обращения: 29.09.2020). 